\title{
Possible ways to attract private investment in a knowledge-based economy
}

\author{
Liudmila Goryainova ${ }^{1}$, Tatiana Maksimova ${ }^{1}$, Olga Zhdanova $^{1}$, Mariia Ermilova ${ }^{1 *}$ \\ ${ }^{1}$ Plekhanov Russian University of Economics, 117997, Moscow, Russia
}

\begin{abstract}
The article substantiates the role of education, puts forward and confirms the hypothesis of the importance and necessity of social partnership for financing and developing education in a knowledge-based economy. To confirm the hypotheses put forward, the evolution of the concepts of social interaction and social responsibility is studied, the laws of social partnership in a knowledge-based economy are substantiated, which allows using the triple helix model to show the need for interaction between the state, universities and corporations to advance along the path of innovative development. The lack of budget funds for the development of education requires the search for other sources of financing of infrastructure facilities for education. The article discusses the use of concessions as a form of public-private partnership in preschool education, which has recently found application in Russia. Based on the study of international best practices, the authors propose using investment funds, in particular, the mechanism of the impact of investment in education as a promising technology.. One of the solutions to these problems is the mutual investment of funds in intellectual property. The formation of endowment funds for financing education and innovation in the knowledge-based economy is also widespread.
\end{abstract}

\section{Introduction}

A distinctive feature of modern realities and general trends of evolutionary processes occurring in national economies is the transition to a knowledge-based economy, which is associated with the transformations taking place in connection with the radical transformation of the methods of generating and transmitting knowledge, the emergence of innovative technologies caused by the third wave of scientific -technical revolution.

Obviously, under these conditions, increases significantly:

\footnotetext{
* Corresponding author: masha080487@ mail.ru
} 
Firstly, the role of education as a sphere in which the necessary competencies are formed, knowledge is created and disseminated - the main resource of the knowledge economy.

Secondly, the need for the establishment and development of institutions that provide a high level of education and influence the formation of a knowledge-based economy, in particular, institutions that form new tools for attracting financing to education.

In terms of quantitative indicators, the economy and education of Russia are successful, but qualitatively they lag behind the countries that occupy places in the top ten. The place of Russia in the world rankings in terms of economic and demographic indicators is determined by the following positions: the volume of gross domestic product per capita at purchasing power parity - 53rd place [1], coverage of higher education - 12th place [2].

The place in the world competitiveness rating of the World Economic Forum is as follows: the quality of professional training is 76th place, innovativeness is 32nd. [3] World experience indicates that it is impossible to achieve the effectiveness of solving social problems and create the conditions for the development of social infrastructure in a market economy in a single state. A positive result can be achieved only based on social partnership as a process tool, which is a system that includes objects, authors and relations between them, taking an institutional form, as well as mechanisms for the implementation of relations in the form of agreements for interactions in order to reach agreement on common tasks.

In this regard, the importance of studying the world experience of innovations in attracting private financing, identifying the problems of their implementation and potential opportunities for the Russian economy is growing.

Currently, there is still a lack of financial support for educational institutions, one of the foundations for the formation and functioning of a knowledge-based economy. Despite the fact that the financing system is constantly updated with new financing mechanisms and tools, the issue of raising capital in the field of education and innovation, especially the private one, remains extremely acute. Tax incentives, as well as the development of new financing mechanisms, and the emergence of new investment institutions on the market can activate investors, for example. The latter can take on a social function, creating the conditions for financing the knowledge economy by many different people, thus involving them not only in the investment process, but also in the process of creating a knowledgebased economy.

\section{Methods}

The theoretical and methodological basis of the work is the scientific and analytical research of Russian and foreign scientists and practitioners on the issues under consideration in the field of sustainable development of a knowledge-based economy. In addition, a number of legislative acts of the Russian Federation were examined that govern public-private partnerships, investment activities, the functioning of investment funds, as well as official statistical information from various sources.

In the process of the study, the authors used a whole complex of general scientific and special methods, which together gave a synergistic effect. In particular, the methods of analysis, synthesis, analogy, and classification are applied. In general, the authors adhered to a systematic method of conducting research, paying attention also to historical and logical methods, as well as using tabular techniques. The synthesis of philosophical, general scientific, private and special research methods allowed for a comprehensive study.

\section{Results}




\subsection{Opportunities for attracting private financing through the mechanism of public- private partnership}

Understanding the importance of education for the creation and evolution of the knowledge economy, the governments of most countries of the world are reforming this sphere, which requires changing the structure of the education and science systems, providing conditions for the formation of a national innovation system, within which integration and social interaction of all economically active actors should be carried out national economy, including the state, universities and business [4].

In the context of insufficient budget expenditures on education in Russia [5], a significant problem for the implementation of education reform areas is the attraction of private funds and competencies in the construction, operation of facilities and in the educational process.

In world practice, to solve the problem of the deficit of state financing, at present, such mechanisms of attracting private capital to education are used: public-private partnerships, endowment funds, investment funds, grants. Of particular interest is the public-private partnership, which has proved to be an effective mechanism for attracting private capital for the implementation of projects in the production and social infrastructure.

The Federal Law "On Public-Private Partnerships, Municipal-Private Partnerships in the Russian Federation and Amending Certain Legislative Acts of the Russian Federation" [6] provides for the consideration of the possibility of private ownership of public infrastructure. One of the main conditions in this case is that the investor must provide full or partial financing of the infrastructure object and its operation for the intended purpose, registered as an encumbrance of the object. This positive change in legislation compared to earlier provisions of regional laws on public-private partnerships makes investing in Russia's social infrastructure more attractive.

In countries characterized by a high level of gross domestic product per capita, where the state provides a decent level of social protection, medical care and education, public-private partnerships in the health and education sectors are more prevalent (Table 1).

Table 1. Public-private partnership projects in Germany and Russia in the context of individual areas of activity (in \% of the total)

\begin{tabular}{|l|l|l|l|l|}
\hline № & German Economy & $\begin{array}{c}\text { Share of the } \\
\text { total number of } \\
\text { projects }\end{array}$ & $\begin{array}{c}\text { Spheres of the } \\
\text { Russian Economy }\end{array}$ & $\begin{array}{c}\text { Share of the } \\
\text { total number of } \\
\text { projects }\end{array}$ \\
\hline 1. & Education & 40 & Education & 6,3 \\
\hline 2. & Federal facilities & 2 & $\begin{array}{l}\text { Transport } \\
\text { infrastructure }\end{array}$ & 26,6 \\
\hline 3. & Sport and culture & 26 & Sports and tourism & 12,7 \\
\hline 4. & $\begin{array}{l}\text { Penitentiary } \\
\text { system }\end{array}$ & 3 & $\begin{array}{l}\text { Community } \\
\text { Infrastructure }\end{array}$ & 17,7 \\
\hline 5. & $\begin{array}{l}\text { Administrative } \\
\text { building }\end{array}$ & 18 & Culture & 1,3 \\
\hline 6. & Healthcare & 3 & Healthcare & 13,9 \\
\hline 7. & Other & 8 & Energetics & 21,5 \\
\hline
\end{tabular}
[7]

Source: compiled by the authors according to the Center for Public-Private Partnership 
So, in Germany, $40 \%$ of public-private partnership projects are in the field of education. In Russia, statistics show other results: transport and energy infrastructure account for about $50 \%$ of all projects, and education only $6.3 \%$. Therefore, we can conclude that there is a correlation between the level of development of the country and the sphere that is chosen to attract investment in it on the principles of public-private partnership [8].

Countries with a high level of socio-economic development give preference to the health and education sectors, and in developing countries and countries with economies in transition, these areas are not priority: the transport infrastructure is the first priority in attracting investments through public-private partnerships: construction and reconstruction of roads, ports, railways, etc.

Based on this, not only the justification for the need to attract private funds in images is significant knowledge in the economy of knowledge, but also the study of world experience of this process in order to adapt to Russia.

Currently, there are 59 projects in the field of preschool and secondary education in Russia, the implementation forms of which are: a concession agreement, an agreement on public-private or municipal-private partnership, of which 11 projects are in operation [9].

\subsection{Transforming investing in a knowledge-based economy}

Another mechanism for attracting private investment in education may be the formation of investment funds. World practice indicates the relevance and effectiveness of this mechanism of financing the education system. In 2007, in the process of searching for alternative investment areas, the concept of "impact investment" was developed. "Impact investment" is definedas "investmentsaimedatcreating a positiveeffectinadditionto financial returns" [10].

A distinctive feature in this concept was not only the combination of financial and social results as a motivation for investment activity, but also the desire of investors to obtain results in the social and / or environmental sphere. Impactinvestments are active generators of positive social and environmental effects, investing in assets, companies and foundations whose capabilities and results are larger than traditional charitable organizations.

In Russian practice, the term impact investment or transformative investment is used to designate this form of investment [11]. We can say that the use of transformative investment is the technology of turning value into value.

An exchange tool to raise funds for investing in such projects is the Exchange Traded Fund (ETF), which is widely traded on the exchange, and is widely used in the West.

In Russia, exchange-traded mutual investment funds can be considered an analogue of ETFs. Exchange-traded mutual investment funds are defined as follows: «Contractual funds are mainly widespread in the countries subject to Romano-Germanic Law. They are created as a property complex pursuant to a co-ownership agreement (agreement with investors). In this case, the management of property constituting the fund is delegated to a management company obliged to act for the benefit of investors. A nominee holder of investment fund assets is an entity performing asset accounting and preservation. The primary source of income for investors is the difference (spread) between buy and sell prices for an investment fund share (investment unit); however, sometimes it is possible to earn a current yield» [12].

Among the difficulties associated with the creation of such funds in Russia are the immaturity of formal institutions, including the legal framework similar to Western practices. Currently, the concept of active introduction of ETFs in the Russian market is being developed. The Bank of Russia significantly simplifies the structure of the collective investment market. The implementation of impact investing will allow combining the advantages of collective investments and exchange-traded instruments and ensure not only 
the attraction of private investors, but also the reduction of risks of potential investors (shareholders). In addition, an investment mechanism through exchange-traded investment funds can optimize the asset management structure.

The authors propose to consider another type of investment funds, which can also contribute to the development of the knowledge economy - intellectual property investment funds.

The main objective of a mutual investment fund of intellectual property should be the financing of innovative activity at its earliest stages, as well as stimulating the development of the market for exclusive rights to the result of intellectual activity as one of the most promising, economically and socially significant markets in the modern world.

On the one hand, a mutual investment fund of intellectual property, like any other mutual investment fund, accumulates temporarily free capital of investors, which helps to solve the problem of finding capital. On the other hand, a mutual investment fund is an institution of financing, since it is through its functioning that capital is redistributed from an investor to people in need of capital (in this situation, to people engaged in innovative activities and contributing to the creation of a knowledge-based economy).

A mutual investment fund of intellectual property should be formed and managed in accordance with the existing regulatory framework governing the activities of investment funds of other types.

The composition of the property of the mutual investment fund of intellectual property is proposed to include:

- exclusive rights to the result of intellectual activity;

-cash;

- shares of Russian joint stock companies;

- shares in the authorized capital of Russian limited liability companies;

- shares of foreign joint stock companies;

- debt instruments, namely:

- bonds of Russian business entities, if the state registration of their issue was accompanied by registration of a securities prospectus or in respect of which a securities issue prospectus was registered, as well as bonds secured by self-supporting insured persons;

- exchange bonds of Russian business entities;

- bonds of foreign issuers and international financial organizations, if they provide for the full repayment of the principal amount and the code assigned to the bonds CFI (classification of financial instruments) has the following meanings: the first letter is the value "D" (debt instruments - debt instruments), the second letter is the value "B" (bonds - bonds), "C" (convertible bonds - convertible bonds);

- Government securities of the Russian Federation, government securities of the constituent entities of the Russian Federation and municipal securities.

In order not to reduce the circle of potential shareholders of a mutual investment fund of intellectual property, investment shares of such a fund should not be limited in circulation, that is, any person should have the opportunity to acquire them. Of course, you can create a mutual investment fund for intellectual property and only for qualified investors, investing in which will be at a higher risk than a mutual investment fund for intellectual property for any investors. However, the decision to limit investment units in circulation should be voluntary, and the law should not introduce a norm according to which the units of a mutual investment fund of intellectual property would be intended only for qualified investors.

Thus, through the operation of a mutual investment fund of intellectual property, firstly, much-needed financing is provided for the development of innovative ideas, secondly, the 
market for exclusive rights to the result of intellectual activity is growing, and thirdly, investors are able to receive income on invested capital.

Mutual investment funds of intellectual property will be interesting for investors, as they provide them with the opportunity to receive high income due to the difference between the sale price and the purchase price of the investment share, the growth of value of which, in turn, depends on the efficiency of managing a mutual investment fund of intellectual property, as well as , for example, from factors such as:

- the success of innovation processes and the possibility of legal protection and commercialization of innovations;

- the demand for exclusive rights to the result of intellectual activity (high demand in the market in question will inevitably lead to an increase in prices due to limited supply);

- increase in the value of shares (shares in the authorized capital) included in the assets of the unit investment fund of intellectual property due to the effective functioning of the person who issued them, primarily in the field of innovation;

- stability of the financial and economic situation of the person issuing debt instruments, especially regarding its ability to pay its debts;

- the presence or absence of positive exchange rate differences.

The operation of a mutual investment fund of intellectual property directly or indirectly can favorably affect the country's economy, which means that mutual investment funds of intellectual property are of interest, and it is advisable to include them in the composition of collective investment institutions, fixing this at the legislative level.

The infrastructure of a mutual investment fund of intellectual property does not fundamentally differ from the infrastructure of mutual investment funds of other types; however, its consideration is necessary to draw up a comprehensive picture of the functioning of a mutual investment fund of intellectual property.

In addition to an integral subject of the infrastructure of any investment funds - public authorities - in the process of functioning of a mutual investment fund of intellectual property, it is necessary:

- management company (is the main subject of the infrastructure of any mutual investment fund, including the mutual investment fund of intellectual property, since it is precisely its actions that ultimately allow investors to receive income from investing in investment units.);

- specialized depository;

- registrar;

- auditor;

- independent appraiser.

Innovation, intellectual property, education and the knowledge economy are interrelated concepts, and the development of each of them is impossible without the evolution of the others. Effective financing of the education system and innovation involves not only the use of adequate sources of funds, tools and forms of their attraction, but also the functioning of an effective mechanism for the circulation of financial resources in the innovation environment. In this regard, the use of intellectual property investment funds is proposed as an element of the knowledge-based economy financing system.

\subsection{Endowment funds in education as a way of financing the knowledge-based economy}


Endowment funds should also be identified as promising mechanisms for attracting private funds to education in order to form a knowledge-based economy. In 2007, the Federal Law "On the Procedure for the Formation and Use of the Target Capital of Non-Profit Organizations" [13] entered into force in Russia. Endowment fund is a domestic analogue of the so-called endowment fund, which accumulates donations from university graduates and interested companies.

The Moscow State Institute of International Relations (MGIMO) owns one of the largest endowment funds in Russia. Among the successful Russian practices, one should also highlight the prospects of the foundation of the Skolkovo Institute of Science and Technology (Skoltekh), whose founders set an ambitious goal: to accumulate $\$ 1$ billion. In this case, the fund will cover up to $30 \%$ of the institute's budget. In ten-year plans - an increase in volume up to $\$ 2$ billion [14]. Among charitable foundations, such as: "Dynasty" and the Vladimir Potanin Fund are noticeably distinguished.

The difference between an endowment and a charitable contribution is the inviolability of donor funds. For example, a university does not have the right to spend the money raised: only investment income goes to its needs. The portfolio structure of the endowment fund is conservative: deposits, bonds of various issuers, a small share of shares, which is explained by the need for the fund to receive income. According to the legislation, a fund can be disbanded if the value of net assets because of trust management of target capital falls by more than $30 \%$ within three years. The fund must bear the costs of the operation, payment for the services of the management company, involving the use of up to $10 \%$ of the target capital.

Among the problems of the functioning of funds, it should be noted the peculiarities of Russian asset management [15]: management companies, as a rule, imply a strategy for a year, while the endowment fund itself is created under Russian law for at least ten years. In most universities, there is no systematic planning of future donations and payments of income from endowment capital;

the principle of equality of generations is not respected: the principle of conservation, and only then the principle of consumption;

external factors are ignored when determining expenditure volumes, which leads to a loss in the volume of funds, or vice versa to excessive accumulation; information on the formation and expenditure of funds of funds is not disclosed.

\section{Discussion}

Understanding the importance of education to create a knowledge economy requires the formation of partnerships between all actors involved in the social process and building an effective system of interaction. Russian practice indicates the need for an active policy in the field of creating a knowledge economy, and one of the main issues is to improve the legislative framework, expanding the capabilities of market participants, on the one hand, but protecting their interests and the interests of society as a whole, on the other. The reduction in budget financing of education in Russia makes it crucial to search for alternative sources and forms of attracting private capital in this area.

Successful world experience is becoming the basis based on which it is possible to develop solutions adapted for the Russian economy. The most attractive now is a publicprivate partnership, but the authors propose to pay more attention to other mechanisms for attracting capital in order to create a knowledge economy. 


\section{Conclusion}

The level of development and dynamism of the innovation sphere provides the basis for sustainable economic growth along an intensive path and has a significant impact on the state of the global economy as a whole. The defining characteristic of modern society is the generation of new ideas, their implementation in practice, the continuous and progressive improvement of existing objects and processes.

Thus, attracting private investment in education is one of the dominant factors for the sustainable development of a knowledge-based economy. The author's concept of attracting private investment in the education system and improving the mechanisms of financing the knowledge-based economy involves the involvement of all economically active actors in the national economy on the principles of social partnership.

Among the most promising areas for improving investment mechanisms in modern conditions, the authors single out such as improving public-private partnerships, adapting successful practices of exchange and mutual investment funds, developing endowment funds. The general basic condition for the successful use of these mechanisms is the improvement of institutional conditions, including, first of all, the creation of the necessary regulatory support system at all the main stages of financing: macro, mezo- and micro levels.

\section{Reference}

1. Data Bank. The World Bank (2020).

2. CenterforHumanitarianTechnologies (2020).

3. The GlobalCompetitivenessReport (2019).

4. I.V. Kosorukova, I.G. Sukhanova, O.D. Kosorukova, N.V. Mirzoyan, N.N. Ivlieva. International Journal of Engineering and Advanced Technology 8 (5), 2220-2225 (2019).

5. Center for Economic and Political Reforms (2020).

6. Federal Law of the Russian Federation "On Public-Private Partnerships, Municipal-Private Partnerships in the Russian Federation and Amending Certain Legislative Acts of the Russian Federation" (2020).

7. 7. Center for public-private partnership (2020).

8. A.N. Leibovich. Accreditation in education. (2013).

9. Unified information system of public-private partnership in the Russian Federation (2020).

10. J.P. Morgan, the Global Impact Investing Network (GIIN) and the Rockefeller Foundation. GlobalResearch. (2020).

11. Transformativeinvesting (impactinvesting) (2020).

12. A.A. Vershinina, L.V. Goryainova, O.A. Zhdanova, T.P. Maksimova. Journal of Internet Banking and Commerce. Special Issue: Finance, Services Sector and Commerce: Innovations and Investments.21, S3(2016).

13. Federal Law of the Russian Federation "On the procedure for the formation and use of the target capital of non-profit organizations" (2020).

14. Skolkovo Institute of Science and Technology (2020).

15. N. Gryzunova, J. Zakharova, M. Gordienko. SGEM 5th international multidisciplinary scientific conference on social sciences and arts. 5, 1.3., 181191 (2018). 